\title{
Implementasi Mainan Susun Balok Seimbang Berbasis Kearifan Lokal Yogyakarta untuk Anak Usia Dini
}

\author{
Suyadi', Issaura Dwi Selvi ${ }^{2}$ \\ Pendidikan Islam Anak Usia Dini, Universitas Islam Negeri Sunan Kalijaga Yogyakarta \\ DOI: $\underline{10.31004 / \text { obsesi.v4i1.345 }}$
}

\begin{abstract}
Abstrak
Teknologi pada era revolusi industri 4.0 memberi pengaruh pada mainan anak. Anak menyukai mainan modern yang tidak ada nilai kearifan lokal. Padahal kearifan lokal dapat menunjang pembangunan nasional. Maka dari itu peneliti melakukan penelitian penerapan mainan susun balok seimbang yang berlandaskan kearifan lokal Yogyakarta. Tujuan penelitian ini adalah untuk mengetahui bagaimana mainan susun balok seimbang kearifan lokal diterapkan pada anak usia 5-6 tahun dan ditinjau dari sudut pandang aspek perkembangan anak dan pengenalan nilai budaya Yogyakarta. Penelitian ini menggunakan penelitian deskriptif kuantitatif tentang penggambaran objek dan subjek penelitian berdasarkan hasil perhitungan data. Metode yang digunakan adalah observasi dan dokumentasi. Sasaran subjek penelitian adalah anak usia 5-6 tahun. Hasil penelitian berdasarkan aspek perkembangan dan aspek kearifan lokal memperoleh data dengan kategori baik sekali. Maka dapat disimpulkan bahwa mainan susun balok seimbang berbasis kearifan lokal Yogyakarta dapat diimplementasikan dalam pembelajaran maupun sebagai alat bermain untuk anak usia 5-6 tahun dengan baik sekali.
\end{abstract}

Kata kunci: Mainan; Susun Balok Seimbang; Kearifan Lokal Yogyakarta.

\begin{abstract}
Technology in the industrial revolution era 4.0 had an influence on children's toys. Children love modern toys that have no local wisdom value. Even though local wisdom can support national development. Therefore, researchers conducted research on the application of balanced beam stacking toys based on Yogyakarta's local wisdom. The purpose of this study is to find out how the blocks stacking toys of local wisdom are applied to children aged 5-6 years and viewed from the point of view of aspects of child development and the introduction of cultural values of Yogyakarta. This research uses descriptive quantitative research on the description of objects and research subjects based on the results of data calculations. The method used is observation and documentation. The target subjects of the study are children aged 5-6 years. The results of research based on aspects of development and aspects of local wisdom obtain data in very good categories. Then it can be concluded that the balanced stacking toy based on Yogyakarta's local wisdom can be implemented both in learning and as a play tool for children aged 5-6 years very well.
\end{abstract}

Keywords: Toy; Balanced Beam Stacking; Yogyakarta's Local Wisdom.

Copyright (c) 2019 Suyadi, Issaura Dwi Selvi

$\triangle$ Corresponding author:

Email Address : issaura.dwiselvi@yahoo.com, yadi_uinjogja@gmail.com (Yogyakarya, Indonesia)

Received 12 September 2019, Accepted 8 December 2019, Published 10 December 2019 


\section{PENDAHULUAN}

Era revolusi industri 4.0 sekarang menuntut perubahan dan perkembangan zaman menjadi lebih canggih dibidang teknologi. Tidak mengherankan apabila sekarang banyak anak-anak sudah tidak asing memainkan mainan-mainan yang modern, bahkan ada mainan yang dapat dikoneksikan ke smartphone maupun internet. Perubahan perkembangan mainan yang pesat ini membuat para orang tua bersemangat untuk memberikan berbagai mainan modern yang terbaik untuk anaknya.

Tidak sulit bagi orang tua untuk mencari mainan modern terbaik di zaman sekarang ini. Mainan dapat mudah ditemukan di toko-toko mainan maupun melalui aplikasi perbelanjaan online. Kebanyakan orang tua lebih tertarik membeli mainan modern yang berbahan dasar plastik dari pada berbahan dasar kayu buatan lokal. Mainan plastik lebih efisien, ekonomis dan berwarna variatif. Padahal ditinjau dari aspek alam, proses penghancuran mainan plastik yang sudah tidak dipakai atau dibuang membutuhkan waktu lama untuk mengurai di tanah. Hal ini diperjelas dari sebuah artikel yang mengatakan bahwa sampah plastik dapat terurai dalam jangka waktu 1000 tahun (Dayana, 2019).

Maka dari itu, guru maupun orangtua harus cerdas dalam memilihkan mainan untuk anak. Selain memiliki konsep modern dan mengandung aspek perkembangan anak, mainan juga harus dapat didaur ulang atau apabila telah tak layak pakai maka tidak akan merusak alam dan bumi. Memanfaatkan bahan alam dapat mengurangi polusi sampah di lingkungan sekitar (Laila and Candraloka, 2019: 77). Meskipun mainan plastik relatif murah dan mudah dalam proses pembuatannya karna melalui mesin, namun sangat penting untuk mempertimbangkan keadaan yang akan terjadi di masa depan.

Salah satu mainan yang paling terbaik menurut peneliti untuk anak dan bumi adalah mainan yang terbuat dari bahan dasar alam itu sendiri yakni terbuat dari kayu. Pada dasarnya mainan kayu yang dipilih atau dibuat dengan bentuk sederhana ataupun rumit harus tetap memiliki tugas dan fungsi yang sama dalam mendukung pertumbuhan dan perkembangan anak. Paling penting memilih mainan adalah aman untuk anak (Nugrahani et al., 2012: 59). Dilihat dari segi keramahan lingkungan, mainan kayu dapat didaur ulang dan tidak terlalu lama terurai di alam dibandingkan mainan yang terbuat dari plastik. Hal ini didukung dengan hasil penyuluhan Tim IKIP PGRI kota Semarang yang mengatakan bahwa pemanfaatan lingkungan seperti kayu pada proses pembuatan mainan berhasil dan ramah terhadap lingkungan (Khasanah et al., 2013: 31).

Pusat kerajinan pembuatan mainan kayu di Indonesia yang sangat terkenal oleh berbagai penjuru negara adalah Yogyakarta. Pembuatan mainan kayu oleh pengrajin dari kota Yogyakarta memiliki karakteristik dan sifat yang berbudaya, tradisional dan kearifan lokal. Kita menyadari bahwa nilai budaya dalam pembelajaran di sekolah tidak seluruhnya sesuai dengan perkembangan zaman. Padahal ragam budaya Indonesia perlu diketahui anak sejak dini. Guru membawa peran penting dalam mengenalkan nilai budaya kearifan lokal, melalui media pembelajaran yang dapat merangsang pengetahuan budaya anak (Astuti, 2016: 1).

Maka dari itu peneliti menawarkan sebuah alat permainan edukatif untuk anak usia 5-6 tahun yang berbasis salah satu kebudayaan Indonesia yakni Mainan Susun Balok Seimbang dengan Kearifan Lokal Yogyakarta. Susun balok seimbang kearifan lokal adalah mainan menyusun balok secara seimbang di atas media kearifan lokal Yogyakarta yaitu andong atau becak. Mainan ini memiliki dua tujuan pembelajaran yakni mengembangkan aspek perkembangan dan mempelajari nilai kearifan lokal Indonesia. Nilai kearifan lokal merupakan penunjang pembangunan nasional (Astiyanto, 2006: 107). Maka dari itu penelitian ini bertujuan untuk memunculkan kembali mainan yang mengandung nilai-nilai kearifan lokal yang menjadi ciri khas budaya Indonesia kepada anak.

Mainan (toy) adalah suatu objek untuk dimainkan (Muliawan, 2009: 17). Mainan dalam Kamus Besar Bahasa Indonesia (KBBI) diartikan sebagai alat untuk digunakan pada saat melakukan bermain ("Kamus Besar Bahasa Indonesia," n.d.). Mainan sama halnya 
dengan pengertian alat permainan edukatif. Mainan memiliki fungsi yang serbaguna meskipun setiap mainan memiliki tugas berbeda-beda, mainan juga dapat mengembangkan lebih dari satu aspek perkembangan serta memiliki nilai budaya (Kurniawan, 2018: 101).

Alat permainan atau mainan yang mempunyai banyak kegunaan dan variasi dalam memainkannya akan lebih membangkitkan minat bermain dari pada alat permainan yang hanya dimainkan dengan satu cara, contohnya seperti balok kubus (Martuti, 2012: 68). Hal ini yang menjadi salah satu alasan peneliti melakukan penelitian dengan mengambil konsep alat permainan balok. Mainan yang diimplementasikan dalam penelitian ini adalah susun balok seimbang. Susun balok seimbang merupakan nama mainan yang peneliti buat untuk anak usia 5-6 tahun. Susun balok seimbang berasal dari tiga suku kata yakni susun, balok, dan seimbang. Yang artinya sebuah alat permainan yang digunakan dengan cara menyusun potongan-potongan balok setinggi-tingginya secara seimbang. Mainan dari balok sangat berpengaruh pada aspek perkembangan anak. Hal ini sesuai dengan penelitian di TK Kuntum Mekar, yang mana hasil mengatakan bahwa mainan balok berhasil diterapkan dalam pembelajaran di sekolah-sekolah dengan baik. Dibuktikan dengan hasil evaluasi anak berkembang sesuai harapan pada aspek perkembangan kognitif, sosial emosional, bahasa, seni, nilai moral dan motorik halus anak (Dea and Latipah, 2017: 194).

Mainan susun balok seimbang dirancang sedemikian rupa agar mengangkat unsur kearifan lokal. Kearifan lokal perlu dikenalkan, dijaga dan dipertahankan oleh anak sejak usia dini. Penanaman nilai kearifan lokal pada anak usia dini dapat dilakukan melalui proses kegiatan belajar mengajar, di rumah, atau di tempat umum lainnya seperti perpustakaan daerah, area bermain dan sebagainya (Nadlir, 2014: 301-330).

Secara baku, kearifan diambil dari kata arif dalam KBBI yang artinya adalah cerdik, pandai, paham, bijaksana, berilmu, mengerti dan memahami. Kearifan diartikan sebagai kebijaksanaan dan kecendekiaan sebagai sarana pembelajaran bagi setiap individu untuk menjadi manusia yang pandai, cerdas dan bijak sana. Pada tahap penerapan kearifan dapat diterapkan pada nilai-nilai dan norma dalam wujud perilaku sesuai dengan etika (normanorma) dan etiket (sopan-santun) yang diberlakukan di masyarakat (Soeseno, 1984: 6).

Kearifan lokal itu sendiri adalah bentuk kecerdasan yang dihasilkan masyarakat kebudayaan tertentu berdasarkan pengalaman yang ditemukan dan dijalani sendiri sehingga menjadi milik bersama oleh kelompok masyarakat tersebut (Rahyono, 2015: 8). Maka definisi dari kearifan lokal Yogyakarta adalah wujud atau bentuk sebuah kecerdasan yang dihasilkan berdasarkan pengalaman hidup masyarakat Yogya sendiri dan bukan dari pengalaman daerah lain.

Ruang lingkup budaya kearifan lokal terbagi menjadi beberapa bagian yaitu: (1) cagar budaya, (2) prasarana budaya, (3) pakaian adat, (4) upacara adat, (5) pariwisata alam, (6) permainan tradisional, (7) warisan budaya, (8) museum, (9) kerajinan dan seni (tari), (10) desa, (11) desa, (12) legenda (cerita), (13) lembaga budaya, (14) makanan budaya, (15) wayang, dan terakhir (16) transportasi tradisional (Chairiyah, 2018: 210). Salah satu yang menjadi fokus penelitian ini adalah mainan susun balok seimbang berbasis kearifan lokal Yogyakarta yaitu pada transportasi tradisional. Transportasi tradisional yang digunakan adalah andong dan becak sebagai media penunjang media permainan.

Perumusan masalah penelitian ini adalah untuk mengetahui bagaimana implementasi mainan susun balok seimbang kearifan lokal Yogyakarta. Penting untuk mengetahui bagaimana mainan ini diterapkan pada anak usia 5-6 tahun dan dipandang dari sudut pandang aspek perkembangan anak, dan pengenalan budaya di Indonesia maupun di manca negara. Maka dari itu penulis membuat judul penelitian ini yaitu "Implementasi Mainan Susun Balok Keseimbangan Berbasis Kearifan Lokal Yogyakarta”. 


\section{METODOLOGI}

Penelitian ini dilakukan dengan penelitian kuantitatif melalui metode deskriptif. Metode deskriptif kuantitatif merupakan metode tentang menggambarkan suatu objek penelitian berdasarkan hasil perhitungan data yang dilakukan oleh peneliti mengenai implementasi mainan susun balok seimbang kearifan lokal Yogyakarta. Teknik pengumpulan data dilakukan dengan metode observasi dan dokumentasi. Sasaran penelitian ini dengan melakukan observasi dan dokumentasi adalah 12 anak yang berusia 56 tahun kelas B di salah satu sekolah TK di Yogyakarta yaitu TK ABA Rawulu Kulon Yogyakarta. Instrumen dalam melakukan penilaian observasi peneliti yaitu berikut ini:

Tabel 1. Instrumen Observasi Aspek Perkembangan

\begin{tabular}{llllll}
\hline No. & \multicolumn{1}{c}{ Aspek Perkembangan } & BSB & BSH & MB & BB \\
\hline 1. & Kognitif & & & \\
2. & Sosial emosional & & \\
3. & Bahasa & & \\
4. & Nilai Moral & & \\
5. & Fisik Motorik Halus & & \\
6. & Seni & & \\
& & & \\
\end{tabular}

Tabel 2 . Instrumen Observasi Aspek Kearifan Lokal Yogyakarta

\begin{tabular}{|c|c|c|c|c|c|}
\hline No & Aspek Kearifan Lokal & BSB & BSH & MB & BB \\
\hline 1. & $\begin{array}{l}\text { Apa jenis transportasi } \\
\text { tradisional Yogyakarta }\end{array}$ & & & & \\
\hline 2. & $\begin{array}{l}\text { Siapa yang mengemudikan } \\
\text { transportasi. }\end{array}$ & & & & \\
\hline 3. & $\begin{array}{l}\text { Bagaimana cara } \\
\text { menggunakan transportasi } \\
\text { tradisional. }\end{array}$ & & & & \\
\hline 4. & $\begin{array}{l}\text { Dimana transportasi } \\
\text { tradisional biasa ditemukan. }\end{array}$ & & & & \\
\hline 5. & $\begin{array}{l}\text { Kapan transportasi } \\
\text { tradisional digunakan. }\end{array}$ & & & & \\
\hline 6. & $\begin{array}{l}\text { Mengapa perlu mengunakan } \\
\text { transportasi tradisional. }\end{array}$ & & & & \\
\hline
\end{tabular}

Teknik analisis data penelitian ini menghitung data kuantitatif dengan teknik deskriptif persentase hasil rata-rata keseluruhan nilai anak usia 5-6 tahun di kelas B. Lembar hasil nilai observasi pada anak di kategorikan berdasarkan skala penilaian Berkembang Sangat Baik (BSB), Berkembang Sesuai Harapan (BSH), Mulai Berkembang (MB), Belum Berkembang (BB) (Direktur Jenderal Pendidikan Anak Usia Dini dan Pendidikan Masyarakat, 2015: 5).

Tabel 3. Kategori Nilai Hasil Observasi

\begin{tabular}{cccccc}
\hline No. & Kategori Penilaian & BSB & BSH & MB & BB \\
\hline 1. & BSB & & & & \\
2. & BSH & & & & \\
3. & MB & & & & \\
4. & BB & & & & \\
\hline
\end{tabular}


Data hasil observasi dimuat dalam bentuk tabel, kemudian menghitung nilai hasil observasi dengan menggunakan rumus sebagai berikut (Sunarti and Rachmawati, 2014: 191).

Nilai Presentase $=\frac{\text { Skor Perolehan }}{\text { Skor Maksimal }} \times 100 \%$

Kemudian nilai presentase observasi diselaraskan dengan kategori yang ditetapkan pada Tabel 2 di bawah ini (Amirono and Daryanto, 2016: 126).

Tabel 4. Kategori Nilai Presentasi Hasil Observasi

\begin{tabular}{ccc}
\hline No. & Skor (\%) & Kategori \\
\hline 1. & $80-100$ & Baik Sekali \\
2. & $70-79$ & Baik \\
3. & $60-69$ & Cukup \\
4. & $<60$ & Kurang \\
\hline
\end{tabular}

\section{HASIL DAN PEMBAHASAN}

Mainan susun balok seimbang kearifan lokal Yogyakarta merupakan alat permainan edukatif yang dibuat peneliti sebagai bentuk produk mainan untuk anak usia 5-6 tahun dengan konsep pembelajaran modern karena menyusun balok secara seimbang setinggitingginya. Mainan ini berfungsi dapat melatih kemampuan kognitif, motorik halus, bahasa, seni budaya, sosial emosional, dan nilai moral anak dalam mencintai budaya Indonesia. Tujuan mainan ini adalah selain meningkatkan enam aspek perkembangan anak, mampu mengenalkan mainan kayu lokal yang khas dengan budaya Yogyakarta ke manca negara dan dunia. Mainan yang memiliki nilai kearifan lokal menjadi pemahaman budaya dalam suatu pembelajaran (Sudarmiani, 2013: 61). Mainan ini memiliki karya seni yang tinggi karena langsung diproduksi oleh pengrajin kayu Yogyakarta.

Mainan kayu ini terbagi menjadi dua komponen yaitu alas dan beberapa potongan balok. Alas mainan ini merupakan sebuah tempat untuk mendirikan susunan balok-balok. Alas mainan yang digunakan merupakan sebuah hasil kerajinan tangan pengrajin kearifan lokal Yogyakarta berupa dua buah media kayu yaitu andong dan becak. Sedangkan potongan balok sebagai komponen penting dalam membangun susunan balok yang tinggitingginya, seimbang dan tidak mudah jatuh.

Ada dua aturan sebelum memainkan mainan yaitu pertama, kesepakatan antara guru dan anak-anak dengan tidak ada paksaan dan kedua, suit atau diundi melalui nomor absen atau permainan kalah dan menang seperti memberi pertanyaan atau rock paper scissor (Anwar-- et al., 2013: 249). Sedangkan peraturan yang peneliti gunakan adalah peraturan pengundian, dengan mengajukan pertanyaan pada anak yang bisa menjawab duluan dapat menggunakan mainan susun balok seimbang kearifan lokal. Contohnya seperti siapa nama Rasulullah SAW, kemudian anak yang menjawab benar pertama dapat bermain duluan.

Langkah-langkah memainkan mainan ini adalah 1) menyiapkan alas dan beberapa potongan balok kayu, 2) anak diminta untuk memilih ingin menggunakan andong atau becak, ataupun bergantian menggunakan keduanya, 3) menyusun potongan-potongan balok kayu satu-persatu di atas media alas baik itu andong ataupun becak. 4) anak menyusun strategi sendiri agar potongan balok tersebut seimbang dan tidak jatuh. 5) anak harus menyusun balok secara seimbang dengan setinggi-tingginya menggunakan banyak balok kayu. Berikut ini contoh gambar mainan susun balok seimbang kearifan lokal Yogyakarta. 


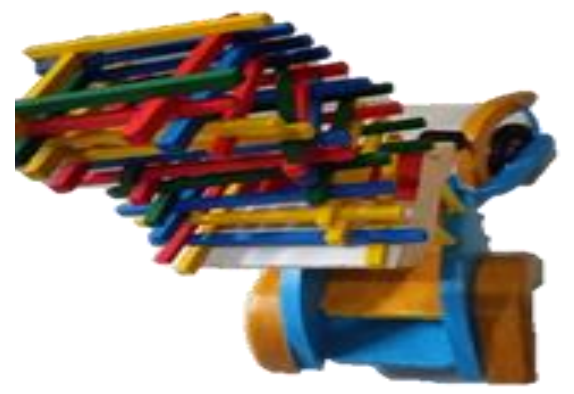

Gambar 1. Mainan Susun Balok Seimbang Becak

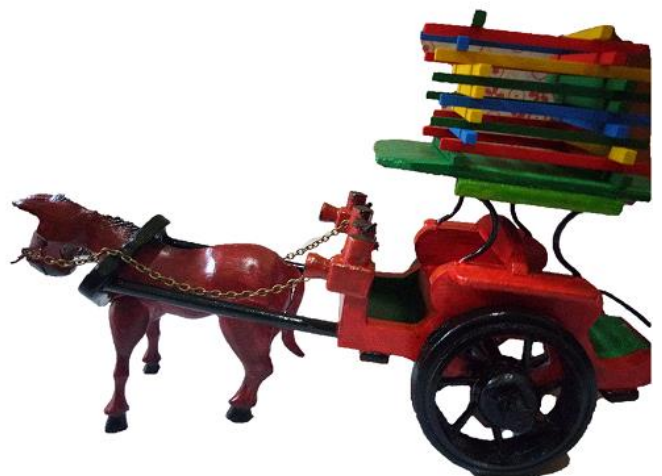

Gambar 2. Mainan Susun Balok Seimbang Andong

Mainan susun balok seimbang kearifan lokal Yogyakara yang dibuat setinggitingginya dapat melatih keseimbangan dan perkiraan. Gerak setiap langkah keseimbangan sangat memerlukan perhatian yang fokus dan penuh keseriusan, kegigihan, kesungguhan dan ketelitian (Direktorat Jenderal Kebudayaan, 1993: 56). Melalui mainan ini anak sebenarnya secara tidak sadar telah melatih diri bagaimana mencari cara dan strategi untuk problem solving.

\section{Aspek Perkembangan}

Penelitian diterapkan pada 12 anak berusia 5-6 tahun. Implementasi mainan susun balok seimbang kearifan lokal Yogyakarta dipandang berdasarkan sudut pandang aspek perkembangan. Mainan kayu susun balok seimbang kearifan lokal Yogyakarta mampu mengembangkan enam bidang aspek perkembangan anak usia 5-6 tahun, yaitu kognitif, bahasa, sosial emosional, fisik motorik, nilai moral dan terutama seni. Peneliti melakukan observasi ke anak, bagaimana perkembangan anak setelah memainkan mainan susun balok seimbang kearifan lokal Yogyakarta dengan berdasarkan indikator 6 aspek perkembangan. Berikut ini hasil penelitian implementasi mainan susun balok seimbang kearifan lokal Yogyakarta yang dinilai berdasarkan aspek perkembangan, sebagai berikut:

Tabel 5. Kategori Nilai Presentasi Hasil Observasi.

\begin{tabular}{clccc}
\hline No. & \multicolumn{1}{c}{$\begin{array}{c}\text { Indikator Aspek } \\
\text { Perkembangan }\end{array}$} & $\begin{array}{c}\text { Jumlah skor } \\
\text { nilai anak }\end{array}$ & $\begin{array}{c}\text { Rata- } \\
\text { rata }\end{array}$ & Kategori \\
\hline 1. & Kognitif & 40 & $83,3 \%$ & Baik Sekali \\
2. & Sosial emosional & 35 & $72 \%$ & Baik \\
3. & Bahasa & 36 & $75 \%$ & Baik \\
4. & Nilai Moral & 48 & $100 \%$ & Baik Sekali \\
5. & Fisik Motorik Halus & 34 & $70,8 \%$ & Baik \\
6. & Seni & 42 & $87,5 \%$ & Baik Sekali \\
& & & $81,43 \%$ & Baik Sekali \\
\hline
\end{tabular}


Pertama, Hasil penelitian diketahui bahwa mendapatkan nilai 83,3\% mainan dengan kategori baik sekali dalam perkembangan kognitif. Ditinjau secara kognitif mainan ini dirancang sedemikian rupa dapat membuat anak berpikir memecahkan masalah ketidakseimbangan dalam menyusun balok dan menghitung berapa jumlah potongan balok yang digunakan. Anak berhasil mengembangkan aspek perkembangan kognitif dengan baik sekali. Hal ini didukung dengan hasil penelitian Rohaeni yang mengatakan bahwa mainan balok berhasil meningkatkan kemampuan kognitif anak (Rohaeni, 2014: 181). Serta hasil penelitian anak kelompok B di RA Al-Hikmah bahwa menerapkan mainan balok dapat meningkatkan kognitif anak sebanyak 94,7 \% (Khasanah, 2019: 14).

Kedua, didapatkan hasil penelitian dalam aspek perkembangan bahasa dengan nilai persenan sebesar $72 \%$ dengan kategori baik. Mainan susun balok seimbang kearifan lokal Yogyakarta baik digunakan karna dapat mengembangkan bahasa anak. Anak menambah kosa kata, mampu bercerita tentang bentuk replika atau nyata, bagian-bagian, cara mengendarai andong atau becak, dan cara memainkan mainan susun balok seimbang tersebut. Mainan balok juga dapat mengembangkan kemampuan bahasa anak, sesuai hasil penelitian Istiarini bahwa dengan nilai 81,25, anak memenuhi kriteria mampu berkembang dalam kemampuan berbicara melalui media mainan balok (Istiarini, 2014: 152).

Ketiga, secara sosial emosional hasil penelitian didapatkan sebesar 70,8\%. Semua anak mau berpartisipasi dalam memainkan mainan susun balok seimbang kearifan lokal Yogyakarta. Sebelum memberi mainan kepada anak peneliti memberikan pertanyaan sederhana, guna anak yang menjawab terlebih dahulu mendapat urutan lebih awal dalam bermain. Sehingga tidak ada anak yang rebutan, dan semangat berpartisipasi dalam menjawab pertanyaan agar bisa antri dinomor awal. Senada dengan penelitian Zamiah yang mengatakan bahwa melalui mainan balok $87,50 \%$ perkembangan sosial emosional anak terbukti sangat baik untuk diterapkan dalam pembelajaran di TK (Zami 'ah, 2013: 5).

Keempat, mainan susun balok seimbang kearifan lokal Yogyakarta sangat berperan penting dalam perkembangan fisik motorik anak, terutama motorik halus. Hasil penelitian mendapatkan $100 \%$ dengan kategori baik sekali. Semua anak diminta memainkan mainan dengan meletakkan setiap potongan-potongan balok secara tersusun, teratur dan seimbang di atas media kayu andong maupun becak. Disini terlihat anak memainkan mainan secara pelan-pelan dan bertahap dengan menggunakan tangan untuk membuat potongan kayu setinggi-tingginya secara seimbang.

Selanjutnya kelima, ditinjau secara nilai moral mendapat hasil nilai sebesar $75 \%$ dengan kategori baik. Sosial emosional diukur dari perilaku anak yang baik tidak merampas mainan yang sedang dipakai temannya. Anak mengangkatkan tangan terlebih dahulu ketika menjawab pertanyaan, tidak menyerobot mainan dari guru. Terakhir keenam, secara seni mainan susun balok seimbang kearifan lokal Yogyakarta mengenalkan anak seni budaya. Sesuai dengan hasil penelitian dengan nilai persenan sebesar $87,5 \%$ dengan kategori baik sekali. Anak mengetahui bahwa ternyata kayu bisa jadi sebuah karya seni budaya yaitu andong dan becak.

Hasil penelitian dari enam aspek perkembangan tersebut diintegrasikan menjadi satu yaitu mendapatkan hasil 81,43 \% dengan kategori baik sekali. Dapat disimpulkan mainan susun balok seimbang kearifan lokal Yogyakarta dapat digunakan secara baik sekali dalam pembelajaran di sekolah, guna mengembangkan enam aspek perkembangan. Hal ini diperjelas berdasarkan hasil penelitian Dimyati yang mengatakan bahwa pengembangan mainan balok dapat meningkatkan kualitas kegiatan belajar mengajar dan aspek perkembangan anak (Dimyati, 2011: 16).

\section{Aspek Kearifan Lokal}

Kearifan lokal adalah nilai-nilai suatu kekayaan culture/budaya yang dijunjung tinggi oleh masyarakat atau suatu golongan (Astuti, 2016: 4). Bentuk kearifan lokal bermacam-macam yang sesuai dengan fungsi dan manfaatnya di suatu budaya masyarakat. 
Kearifan lokal memiliki manfaat yang banyak untuk anak usia dini yaitu mengembangkan aspek perkembangan anak, karakter anak, mengembangkan nilai kasih sayang dan gotong royong, mengembangkan kecerdasan emosi, dan kecerdasan logis matematis anak. Konsep kearifan lokal dapat menjadi pegangan guru dan sangat baik untuk diterapkan pada pembelajaran di kelas (Tinja et al., 2017: 1261).

Mainan susun balok seimbang berbasis kearifan lokal Yogyakarta yang digunakan pada penelitian ini adalah masuk dalam ruang lingkup transportasi tradisional. Implementasi mainan susun balok seimbang berbasis kearifan lokal Yogyakarta yakni bertujuan untuk mengenalkan alat transportasi umum kepada anak usia 5-6 tahun baik dari negara Indonesia sendiri maupun negara asing yaitu andong dan becak. Hasil penerapan mainan susun balok seimbang kearifan lokal mendapatkan anak berkembang sesuai harapan dalam mengenal dan menceritakan kembali mengenai tema kearifan lokal Yogyakarta.

Tabel 6. Kategori Nilai Presentase Hasil Observasi

\begin{tabular}{ccccc}
\hline No. & $\begin{array}{c}\text { Indikator } \\
\text { penilaian }\end{array}$ & $\begin{array}{c}\text { Jumlah Skor Nilai } \\
\text { anak }\end{array}$ & Rata-rata & Kategori \\
\hline 1. & Apa & 48 & $100 \%$ & Baik Sekali \\
2. & Dimana & 48 & $100 \%$ & Baik Sekali \\
3. & Kapan & 48 & $100 \%$ & Baik Sekali \\
4. & Siapa & 48 & $100 \%$ & Baik Sekali \\
5. & Bagaimana & 40 & $83,3 \%$ & Baik Sekali \\
6. & Mengapa & 34 & $70 \%$ & Baik Sekali \\
& & & $92,3 \%$ & Baik Sekali \\
\hline
\end{tabular}

Hasil penerapan mainan susun balok seimbang menemukan bahwa dari 12 anak yang di observasi, hasil penelitian sebesar 100\% untuk kategi indikator apa. Anak mampu bercerita dan menjelaskan apa jenis-jenis transportasi tradisional yaitu andong dan becak, bagian-bagian andong dan becak seperti pada andong meliputi: kuda, kusir, andong itu sendiri. Sedangkan becak, ada tempat duduk, penutup becak, kayuh becak. Selanjutnya hasil penelitian indikator bagaimana mendapatkan hasil sebesar 83,3\% anak dapat menjelaskan bagaimana menggunakan becak yaitu dengan dikayuh seperti bermain sepeda dan penumpang duduk di depan, sedangkan andong yaitu kusir mengayunkan tali pada kuda untuk menjalan andong dan penumpang duduk di belakang.

Hasil penelitian indikator dimana mendapatkan nilai $100 \%$ anak dapat menceritakan dimana becak dan andong dapat ditemukan tidak di setiap jalan, hanya titik tertentu untuk menemukan becak di pasar, tempat wisata dan andong ditemukan di tempat wisata. berapa jumlah penumpang andong dan becak. Selanjutnya hasil penelitian indikator kapan mendapatkan nilai presentase $100 \%$, anak dapat menceritakan kapan becak dan andong digunakan, anak menjelaskan bahwa andong dapat digunakan dari pagi sampai malam ditempat wisata. Sama halnya dengan becak dari pagi sampai malam ditempat wisata, namun di pasar hanya sampai sore. Anak mampu menceritakan kembali mengapa perlu mengendarai transportasi yaitu andong dan becak yang sudah mulai jarang terlihat di daerah-daerah lain.

Nilai presentasi indikator siapa mendapatkan nilai sebesar 100\%, ketika anak ditanya siapa yang mengemudi andong. Kemudian nilai presentasi indikator mengapa mendapat nilai $70 \%$. Anak ditanya mengapa kita harus naik transportasi tradisional. Anak dapat menjawab karena harus melestarikan transportasi tradisional di Indonesia. Andong dan becak dapat dikenalkan kepada orang-orang dari berbagai manca negara.

Berdasarkan hasil penilaian observasi implementasi mainan susun balok seimbang dalam aspek kearifan lokal Yogyakarta mendapatkan 92,3\% mainan sangat baik diterapkan pada anak usia 5-6 tahun. Anak dapat berkembang sesuai harapan dalam memahami kearifan lokal Yogyakarta. Maka dari itu dapat disimpulkan bahwa anak dapat memahami konsep kearifan lokal melalui bermain mainan susun balok seimbang kearifan lokal 
Yogyakarta. Dapat diharapkan mainan susun balok menjadi batu loncatan untuk mengenalkan nilai kearifan lokal budaya Indonesia terutama Yogyakarta sejak dini baik pembelajaran untuk anak Indonesia di provinsi-provinsi selain Yogyakarta, juga mengenalkan pada anak-anak di manca negara.

Melalui kearifan Yogyakarta, mainan susun balok seimbang menjadi sebuah bentuk identitas kebudayaan Indonesia, menumbuhkan harga diri dan percaya diri terhadap kebudayaan, mampu meningkatkan martabat bangsa dan negara, hasil karya anak bangsa dan menjadi batu loncatan untuk menyebarluaskan kebudayaan Indonesia ke manca negara agar tidak diambil negara lain dan tidak punah dimasyarakat. Hal ini sesuai dengan hasil penelitian dalam jurnal ilmiah pendidikan prasekolah dan sekolah awal (INDRIA) yang mengatakan bahwa melestarikan seni budaya dapat diterapkan dalam pembelajaran anak usia dini melalui tema kearifan lokal (Wulansari, 2017: 1). Karena itu sangat penting menjaga kelestarian nilai kearifan lokal Yogyakarta, terutama Indonesia agar tidak mengalami kepunahan dalam nilai seni budaya.

\section{SIMPULAN}

Mainan susun balok seimbang kearifan lokal Yogyakarta berhasil diterapkan pada anak usia 5-6 tahun dengan baik sekali. Mainan susun balok seimbang kearifan Yogyakarta dapat meningkatkan enam aspek perkembangan dan mengenalkan nilai budaya Indonesia. Mainan ini diharapkan sebagai penunjang pembangunan nasional dan mengenalkan nilai budaya Indonesia ke manca negara.

\section{UCAPAN TERIMAKASIH}

Terimakasih kepada ALLAH SWT, Tuhan semesta Alam. Terimakasih kepada baginda Rasulullah SAW. Terimakasih kepada orang tua. Terimakasih kepada Universitas Islam Negeri Sunan Kalijaga Yogyakarta.

\section{DAFTAR PUSTAKA}

Amirono, M.T., Daryanto, 2016. Evaluasi Dan Penilaian Pembelajaran Kurikulum 2013. Gava Media, Yogyakarta.

Anwar --, T, M., Ibrahim, H., 2013. Model Pengembangan Alat Permainan Edukatif Berbasis Sosial Budaya Pada Pembelajaran Anak Didik Kelompok Bermain. J. Pendidik. Dan Kebud. 19(2), 236-251-251. Https:// Doi.Org/10.24832/Jpnk.V19i2.283

Astiyanto, H., 2006. Filsafat Jawa Menggali Butir-Butir Kearifan Lokal. Warta Pustaka, Yogyakarta.

Astuti, S.D., 2016. Transmisi Budaya Dan Kearifan Lokal Pada Pendidikan Islam Anak Usia Dini. Jurnal Penelittian 13(1), 1-14. Https:/ / Doi.Org/10.28918/Jupe.V13i1.1190

Chairiyah, C., 2018. Implementasi Pendidikan Karakter Melalui Nilai-Nilai Kearifan Lokal Di Sd Tamansiswa Jetis Yogyakarta. Trihayu Jurnal Pendidikan Ke-Sd-An 4(1), 208-215.

Dayana, A.S., 2019. Mengenal Jenis Sampah Yang Perlu Waktu Lama Untuk Hancur Tirto.Id Url Https://Tirto.Id/Mengenal-Jenis-Sampah-Yang-Perlu-Waktu-LamaUntuk-Hancur-Ejfk (Accessed 12.5.19).

Dea, L.F., Latipah, E., 2017. Pengembangan Kemampuan Kognitif Dan Sosial-Emosional Melalui Penerapan Media Balok Dan Bermain Peran Pada Siswa Tk Kuntum Mekar, Lampung | Al-Athfal: Jurnal Pendidikan Anak 3(2), 185-196.

Dimyati, J., 2011. Pengembangan Alat Permainan Edukatif (Ape) Jenis Balok Untuk Meningkatkan Kualitas Pembelajaran Di Taman Kanak-Kanak. Jurnal Khazanah Pendidik. 3(2), 1-18.

Direktorat Jenderal Kebudayaan, 1993. Transformasi Nilai Permainan Rakyat Daerah Istimewa Yogyakarta. Departemen Pendidikan Dan Kebudayaan, Yogyakarta.

Direktur Jenderal Pendidikan Anak Usia Dini Dan Pendidikan Masyarakat, 2015. Penilaian Pembelajaran Anak Usia Dini. Direktorat Pembinaan Pendidikan Anak Usia Dini, Jakarta. 
Istiarini, R., 2014. Peningkatan Kemampuan Berbicara Melalui Bermain Balok. Jurnal Pendidikan Usia Dini 8(1), 145-154.

Kamus Besar Bahasa Indonesia. 2016. Url Https://kbbi.kemdikbud.go.id/ (Accessed 12.12.19).

Khasanah, I., Djariyo, D., Damayani, A.T., Mushafanah, Q., 2013. Pemanfaatan Lingkungan Dan Barang Bekas Sebagai Alat Permainan Edukatif (Ape) Bagi Kader Pos Paud Kelurahan Tambak Rejo Semarang. E-Dimas Jurnal Pengabdian kepada Masyarakat 4(2), 24-32. Https:/ / Doi.Org/10.26877/E-Dimas.V4i2.1565

Khasanah, I.N., 2019. Penerapan Bermain Balok Untuk Meningkatkan Kemampuan Kognitif Anak Kelompok B Di Raudlatul Athfal Al-Hikmah Sengon. J. Dewantara 1, 14-18.

Kurniawan, M.R., 2018. Permainan Tradisional Yogyakarta Sebagai Sumber Belajar Alternatif Berbasis Kearifan Lokal Bagi Pembelajaran Di Sekolah Dasar. Premiere Educ. Jurnal Pendidikan Dasar Dan Pembelajaran 8(2), 98-111. Https://Doi.Org/10.25273/Pe.V8i2.2697

Laila, A.N., Candraloka, O.R., 2019. Pemanfaatan Potensi Alam Sebagai Alat Permainan Edukatif Di Paud Delima Jobokuto Jepara. E-Dimas Jurnal Pengabdian Kepada Masyarakat 10(1), 76-82. Https://Doi.Org/10.26877/E-Dimas.V10i1.2883

Martuti, A., 2012. Mengelola Paud Dengan Aneka Permainan Meraih Kecerdasan Majemuk. Kreasi Wacana, Yogyakarta.

Muliawan, J.U., 2009. Tips Jitu Memilih Mainan Positif \& Kreatif Untuk Anak Anda. Diva Press, Yogyakarta.

Nadlir, M., 2014. Urgensi Pembelajaran Berbasis Kearifan Lokal. J. Pendidik. Agama Islam $\begin{array}{llll}\text { Jurnal Islamic } & \text { Education } & \text { 299-330. }\end{array}$ Https:/ / Doi.Org/10.15642/Jpai.2014.2.2.299-330

Nugrahani, D., Alfiah, A., Khasanah, I., Zahraini, D.A., 2012. Alat Permainain Edukatif Berbasis Kontekstual Sebagai Media Pembelajaran Bagi Pendidikan Anak Usia Dini. E-Dimas Jurnal Pengabdian Kepada Masyarakat 3(2), 58-63. Https:/ / Doi.Org/10.26877/E-Dimas.V3i2.1551

Rahyono, F.X., 2015. Kearifan Budaya Dalam Kata. Wedatama Widya Sastra, Jakarta.

Rohaeni, E., 2014. Penerapan Metode Bermain Balok Dalam Mengembangkan Nilai Kognitif Anak Usia Dini Pada Paud Nuansa Kota Bandung. Empower. Jurnal Ilmu Program Studi Pendidikan Luar Sekolah. 3(2), 181-197.

Soeseno, F.M., 1984. Etika Jawa: Sebuah Analisa Falsafi Tentang Kebijaksanaan Hidup Jawa. Djambatan, Jakarta.

Sudarmiani, S., 2013. Membangun Karakter Anak Dengan Budaya Kearifan Lokal Dalam Proses Pembelajaran Di Sekolah. Equilib. Jurnal Ilmu Ekonomi Dan Pembelajarannya 1(1), 54-72. Https://Doi.Org/10.25273/Equilibrium.V1i1.556

Sunarti, Rachmawati, S., 2014. Penilaian Dalam Kurikulum 2013 Membantu Guru Dan Calon Guru Mengetahui Langkah-Langkah Penilaian Pembelajaran. C.V Andi Offset, Yogyakarta.

Tinja, Y., Towaf, S.M., Hariyono, H., 2017. Pengembangan Bahan Ajar Tematik Berbasis Kearifan Lokal Sebagai Upaya Melestarikan Nilai Budaya Pada Siswa Sekolah Dasar. Jurnal Pendidikan Teori Penelitian Dan Pengembangan 2, 1257-1261.

Wulansari, B.Y., 2017. Pelestarian Seni Budaya Dan Permainan Tradisional Melalui Tema Kearifan Lokal Dalam Kurikulum Pendidikan Anak Usia Dini. Jurnal Indria Jurnal Ilmu Pendidikan Prasekolah Dan Sekolah Awal 2(1), 1-11. Https:/ / Doi.Org/10.24269/Jin.V2n1.2017.Pp1-11

Zami`Ah, N., 2013. Pemanfaatan Media Permainan Balok Untuk Meningkatkan Kemampuan Sosial Emosional Anak Kelompok A Di PPT Kuncup Harapan Semolowaru Surabaya. Jurnal PAUD Teratai 2(3), 1-6. 